\title{
Beta Radiation
}

National Cancer Institute

\section{Source}

National Cancer Institute. Beta Radiation. NCI Thesaurus. Code C16535.

Radiation of beta particles during radioactive decay. 